\title{
MODEL PARIWISATA ISLAMI DI KABUPATEN ACEH SINGKIL
}

\author{
Anismar \\ Program Studi Ilmu Komunikasi Universitas Malikussaleh \\ email:anismar@unimal.ac.id
}

\begin{abstract}
ABSTRAK
Kabupaten Aceh Singkil merupakan sebuah daerah di Propinsi Aceh yang mempunyai potensi alamnya sangat mempesona bila dibandingkan dengan daerah lain yang ada di Aceh. Namun sampai sekarang usaha pengembangan kepariwisataannya di Kabupaten tersebut seperti "kura-kura berjalan di atas batu". Hal ini dapat dilihat dari proses pembangunannya yang sangat lambat malah nyaris tidak terlihat, pada hal dari potensi alam dan letak wilayahnya sangat strategis.Hal ini dapat diduga karena tidak didukung dengan sumber daya manusia (SDM), mengingat daerah ini masih tergolang muda menjadi Kabupaten yang ada di Aceh, sehingga sampai sekarang belum ada arah atau konsep apapun dalam pengembangan kepariwisataan di Kabupaten Aceh Singkil. Analisa data dalam penelitian ini dilakukan secara deskriptif. Data dianalisis dalam bentuk langsung secara terus menerus, dengan cara mengelompokkan data sesuai dengan permasalahan penelitian. Setelah data diperoleh pola, bentuk bahkan tema baru dalam penelitian. Selanjutnya semua data dianalisis berdasarkan hasil penelitian yang diperoleh di lapangan melalui pendekatan observasi, dokumentasi dan wawancara dari seluruh informan sasaran penelitian. Metode penelitian yang digunakan dalam penelitian ini adalah metode deskriptif dengan pendekatan kualitatif. Karena penelitian ini bertujuan menggambarkan sifat-sifat, keadaan, serta gejala individu atau kelompok tertentu dalam kaitannya dengan hubungan budaya dan sosial kemasyarakatan.
\end{abstract}

Kata kunci: model kepariwisataan, Wisata Islami, dan Aceh Singkil

\section{PENDAHULUAN}

Kabupaten Aceh Singkil merupakan sebuah daerah termasuk dalam Propinsi Aceh, yang mempunyai keindahan alam sangat mempesona. Wisata bahari dengan 99 pulau yang terdapat di Kecamatan Pulau Banyak, senantiasa menanti pengunjung. Bentang alamnya yang terdiri dari bagian jajaran Bukit Barisan dengan beberapa sungai yang indah merupakan areal petualangan dalam wisata alam bagi kalangan pemuda dan remaja pecinta alam, lintas alam dan sebagainya, serta dengan kesenian tradisionalnya yang sangat unik dan menarik, bila dibandingkan dengan daerah-daerah yang lain di nusantara ini. Kesemua 
potensi ini bila dikembangkan dan ditata lebih maksimal lagi, maka tidak mustahil pada masa yang akan datang pendapatan daerah menjadi idola dari sektor ini, seperti Pulau Bali pada saat sekarang.

Setiap usaha pengembangan kepariwisataan sangat perlu memperhatikan serta mempelajari nilai-nilai yang ada dalam masyarakat. Karena itu merupakan salah satu kenyataan yang hidup didalam masyarakat. Belum tentu semua nilai yang hidup dalam masyarakat itu bertentangan dengan menghambat usaha-usaha pembangunan. Bahkan mungkin, dan sering kali telah dibuktikan oleh ahli-ahli ilmu sosial, bahwa sebagian dari nilai-nilai dari suatu masyarakat, termasuk masyarakat yang dianggap terbelakang atau belum maju, ada mempunyai sifat atau pengaruh positif terhadap usaha pembangunan kalau saja tahu dan pandai memakainya (Alfian, $1986: 266$ ).

Selama ini di Propinsi Aceh pada umumnya, dalam pengembangan pariwisata selalu berorientasi pada nilai-nilai agama (konsep islami). Namun dilapangan kita lihat, arah konsep tersebut belum juga terwujud, malah cenderung berorientasikan kepada konsep Pusat yaitu dengan konsep "Saptapesona"nya. Konsep ini belum tentu cocok untuk dikembangkan di Kabupaten Aceh Singkil, karena tradisi masyarakatnya sangat berbeda dengan masyarakat yang ada di tempat lain terutama diluar Propinsi Aceh.

Dari hasil pengamatan sementara dapat diketahui bahwa, pada umumnya masyarakat di Kabupaten Aceh Singkil, mempersepsikan kegiatan kepariwisataan dengan hal-hal yang negatif, misalnya dengan munculnya pariwisata maka akan muncul pula pola pergaulan bebas dikalangan remaja, dan berubahnya pola pikir masyarakat kearah modernis (yang dipersepsikan negatif). Dengan demikian, program pengembangan pariwisata oleh Pemerintahan Daerah selalu dipersepsikan hal-hal yang negatf oleh masyarakat, sehingga dilapangan terdapat banyak kendala yang akan dihadapi.

Potensi kepariwisataan yang terdapat di Kabupaten Aceh Singkil tersebut belum dapat diandalkan sebagai suatu aset yang mampu mendatangkan penghasilan karena potensi objek wisata tersebut belum dimanfaatkan secara 
optimal. Sementara kawasan pariwisata yang telah dikembangkan masih belum dikelola dengan baik seperti halnya daerah tujuan wisata Pulau Banyak.

Sebagian besar masyarakat Aceh Singkil menganut agama Islam yang fanatik. Secara keseluruhan jumlah terperinci penganut agama di Aceh Singkil, Islam 78722 orang, Protestan 841 orang, Katolik 23 orang dan Iain-lain 241 orang (Aceh Singkil dalam angka $2018: 62$ )

Ajaran Islam terpancang di bumi Aceh Singkil sudah sejak beberapa abad yang silam. Tidaklah mengherankan bila aqidahnya mengakar dalam segala sendi kehidupan. Pantas jika Islam menjadi landasan utama pola pikir dan pola tingkah segenap penduduknya, hal itu terbukti dalam kehidupan mereka sehari-hari, dimana layak tidaknya suatu sikap dilihat dari benar tidaknya dan halal haramnya semuanya menurut kacamata Islam.

Pada satu sisi fanatisme terhadap Islam menyelamatkan daerah ini dari penduduk penjajah. Terbukti dari 350 tahun masa penjajah Belanda di Indonesia, Aceh secara umum dan khususnya Aceh Singkil hanya diduduki 43 tahun, itu pun tidak menguasai semua daerah jajahan, hanya daerah-daerah tertentu saja yang dapat mereka duduki. Oleh karena Islam mengajarkan agar tidak mau menerima kepemimpinan orang kafir yang boleh jadi akan merusak aqidah dan tentu hal itu menyesatkan. Fanatisme terhadap Islam tersebut bisa dilihat dari pola pembinaan terhadap anak-anak. Sejak dini mereka sudah diperkenalkan kepada Al-Qur'an, juga sedikit demi sedikit diajarkan bahasa arab. Sebab, kepandaian mengaji dan bahasa arab seorang anak menjadi kebanggaan orang tua, disamping itu menambah wibawa sebuah keluarga, sehingga banyak ulama di Indonesia ini lahir di bumi Aceh Singkil.

\section{LANDASAN TEORI}

Menurut Yoeti (1997 : 103) kata pariwisata ditinjau dari etimologis ialah berasal dari bahasa sanskerta, sesungguhnya bukanlah berarti "tourisme" (bahasa Belanda) atau "tourism" (bahasa Inggris). Kata parawisata, menurut pengertian ini, sinonim dengan pengertian "tour", pendapat ini berdasarkan pemikiran sebagai berikut: kata pariwisata terdiri dari dua suku kata yaitu masing-masing 
kata "pari" dan "wisata". Pari, berarti banyak, berkali-kali, berputar-putar lengkap (ingat kata dari paripurna), sedangkan wisata, berarti perjalanan, bepergian yang dalam hal ini sinonim dengan kata "travel” (dalam bahasa Inggris). Atas dasar itu, maka kata " pariwisata" seharusnya diartikan sebagai perjalanan yang dilakukan berkali-kali dan berputar-putar, dari satu tempat ke tempat yang lain, yang dalam bahasa Inggris disebut dengan kata "tour" sedangkan untuk pengertian jamak, kata "pariwisata" dapat digunakan kata "tourisme" atau "tourism".

Sedangkan di Indonesia, pengertian "wisata", "wisatawan" dan "parawisata", sebagaimana tercantum dalam Undang-Undang Republik Indonesia Nomor 9/1990 adalah :

- Wisata adalah kegiatan perjalanan atau sebagian dari kegiatan tersebut yang dilakuakn secara sukarela serta bersifat sementara atau menikmati objek dan daya tarik wisata.

- Wisatawan adalah orang yang melakukan kegiatan wisata

- Pariwisata adalah segala sesuatu yang berhubungan dengan wisata, termasuk pengusahaan objek dan daya tarik wisata serta usaha-usaha yang terkait di bidang tersebut.

Demikian konsep atau batasan pariwisata dan definisi wisatawan dewasa ini, memang kalau disimak dengan baik, antara pakar yang satu dengan pakar yang lain mengajukan konsep yang berbeda. Akan tetatapi kalau ditarik benang merah dari konsep-konsep ini dapatlah diketahui bahwa, sebenarnya pariwisata ini tidak lain adalah perpindahan (perjalanan) seseorang dari tempat dimana ia tinggal (hidup) ke tempat yang baru (tujuan wisata) dan bertujuan untuk menikmati perjalanan itu dengan berbagai maksud.

Berpijak pada Undang-Undang No. 18 Tahun 2001, tentang pemberian otonomi kbusus bagi Provinsi Nanggroe Aceh Darussalam, memberi perubahan mendasar di dalam penyelenggaraan pemerintah di Provinsi Nanggroe Aceh Darussalam, termasuk dalam bidang kepariwisataan, juga dengan UndangUndang No.44 Tahun 2000, tentang pelaksanaan Syari'at Islam, bagi warga Nanggroe Aceh Darussalam, yang mempunyai batas-batas dan warna pelaksanaan 
kepariwisataan tersebut adalah pada objek-objek dan kawasan wisata para pengunjung harus menjaga dan memelihara norma, adat istiadat masyarakat Islam (hal yang dilarang dalam agama Islam). Hal ini juga berlaku di Bali, pengunjung tetap dilarang berjalan-jalan pada hari nyepi, atau masuk pura, bagi orang perempuan yang sedang menstruasi. Diharapkan program kepariwisataan Nanggroe Aceh Darussalam dikembangkan dengan tatanan yang spesifik sesuai dengan potensi dan aspirasi masyarakat Aceh dengan mengedepankan nilai-nilai agama dan budaya.

Dalam Qanun Propinsi Nanggroe Aceh Darussalam No. 20 Tahun 2001, tentang Pelaksanaan Syari'at Islam bidang aqidah, ibadah dan Syari'at Islam, pada bab pendahuluan point a dan b dijelaskan bahwa :

a. Aqidah dan ibadah merupakan bagian pokok pengamalan Syari'at Islam yang perlu mendapat perlindungan dan pembinaan sehingga terbina dan terpelihara dalam kehidupan bermasyarakat, berbangsa dan bernegara di Provinsi Nanggroe Aceh Darussalam;

b. Kehidupan masyarakat Aceh yang Islami dan menjunjung tinggi ajaran Islam merupakan landasan dalam mewujudkan kesejahteraan lahir dan batin, baik pribadi keluarga dan masyarakat.

\section{METODE}

Metode penelitian yang digunakan dalam penelitian ini adalah metode deskriptif dengan pendekatan kualitatif. Menurut Hyman (dalam Tan, 1997 : 42), penelitian yang bersifat deskriptif bertujuan menggambarkan sifat-sifat, keadaan, gejala suatu individu atau kelompok tertentu atau untuk menentukan frekuensi adanya hubungan tertentu antara suatu gejala lain dalam masyarakat. Sejalan dengan itu, Rusidi (1999 : 18) menjelaskan penelitian deskriptif bermaksud menggambarkan fenomena empirik yang disertai dengan penafsiranpenafsirannya dengan tujuan memperoleh gambaran setepat realitanya.

Mengenai pendekatan kualitatif Bogdan dan Taylor (dalam Moleong, $2000: 3)$ menyatakan bahwa pendekatan kualitatif merupakan prosedur penelitian yang menghasilkan data deskriptif berupa kata-kata tertulis atau lisan dari orang- 
orang dan perilaku yang dapat diamati. Dalam operasionalisasi penelitian dilapangan, peneliti bertindak sebagai instrument peneliti. Peneliti melakukan pengamatan dan wawancara serta berusaha memahami dan menganalisanya. Langkah-langkah dilapangan dilakukan secara sistematik sebagai usaha menjawab sejumlah pertanyaan yang telah dipersiapkan.

\section{HASIL DAN PEMBAHASAN}

Kabupaten Aceh Singkil memiliki potensi pariwisata yang luar biasa, baik yang sudah direkayasa maupun yang sedang dan dalam menanti pengembangan. Wisata bahari baik disepanjang pantai maupun disekitar Kepulauan Banyak senantiasa menanti pengunjung. Bentang alamnya yang terdiri dari bagian jajaran Bukit Barisan dengan beberapa gunung merupakan areal petualangan dalam wisata alam bagi kalangan pemuda dan remaja pecinta alam, pendaki gunung, kemping, lintas alam, dan sebagainya.

Pada zaman dahulu kala para pedagang dari Gujarat, Turki, Madagaskar yang melakukan bartel hasil bumi di pelabuhan Singkil tak pernah mau membuang kesempatan untuk singgah di Kepulauan Banyak atau Pulau-Pulau Bagu dan Bangkaru maupun pulau-pulau kecil lainnya yang tak terhitung jumlahnya.

Selain wisata bahari, di Kepulauan Banyak dan wisata petualangan menyesuri sungai Alas. Aceh Singkil masih memiliki objek-objek wisata lain yang tidak sedikit jumlahnya. Objek-objek wisata tersebut meliputi wisata pantai, wisata lintas alam, wisata budaya, wisata ilmiah, dan wisata ekonomi.

Sebagian kecil wisata bahari telah dikemukakan diatas. Meski demikian berbagai bentuk wisata lainnya diberbagai tempat senantiasa menarik bagi para pengelana (turis).

Islam juga menganjurkan untuk mengambil pelajaran dari kehidupan bahari sebagaimana dijelaskan dalam Surat Al-lsra' ayat 66.

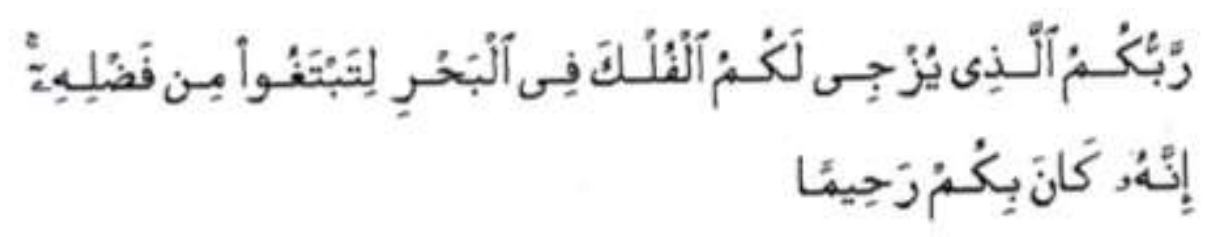


Artinya :

“ Tuhanmu yang melayarkan kapal untuk mu di laut, supaya dapat kamu mencari karuniaNya (rizkiNya). Sesungguhnya Dia penyayang kepada mu".

Sulit dibayangkan masyarakat disekitar kawasan wisata dapat berkembang tanpa harus merubah lingkungannya, termasuk lingkungan sosial budayanya, tanpa keharusan memperlonggar aspek religi yang dominan sebagai umat beragama (Islam). Dapat dipahami, bagaimana proses perkembangan masyarakat di sekitar objek wisata dalam hubungannya dengan pihak wisatawan ditengahtengah perubahan sosial yang terjadi dengan pesat dalam era globalisasi saat ini. Kecanggihan media elektronika di bidang informasi dan komunikasi akhir-akhir ini, telah membuat kita dengan segera menyaksikan pentas dunia yang mempertontonkan aktivitas hidup dan kehidupan manusia yang seolah-olah mengesampingkan norma dan kaidah kesusilaan yang sarat dengan doktrin nilainilai religi sebagai unsur norma agama.

Di bidang keagamaan, tampakiiya kegiatan kepariwisataan dapat dipastikan mempunyai dampak yang serius. Publikasi hasil-hasil penelitian yang sudah dilakukan sangat terbatas. Dampak tersebut cenderung merupakan tubrukan moralitas yang tampak pada aktivitas keagamaan masyarakat terutama bagi masyarakat disekitar daerah tujuan wisata.

Bila dihubungan dengan pengamatan dilapangan, masyarakat (responden) yang menyatakan berdampak negatif dari kehadiran wisatawan, adalah masyarakat (responden) yang melihat dari segi pergaulan dan pakaian wisatawan sangat tidak sopan dalam pandangan agama. Sedangkan yang masyarakat (responden) yang menilai menguntungkan dalam aktivitas keagamaan, karena melihat ada wisatawan yang datang ke objek wisata dengan tujuan ilmiah (penelitian) dan wisatawan dalam kehadiranya menyempatkan diri bertukar pikiran (membagi pengalaman) dengan masyarakat setempat tentang pengetahuan agama.

Bagi masyarakat Aceh Singkil sudah lebih dari pada jelas, bahwa agama, adat dan budaya merupakan bagian yang tak terpisahkan dari kehidupan spiritual 
kesehariannya. Perilaku seseorang dalam masyarakat sangat ditentukan oleh penghayatan dan cara ia menerapkan adat disekelilingnya.

Namun karena kesalahan dan penyimpangan pengoperasian pariwisata seolah-olah tanpa adanya ansur seks atau embel-embelnya (disco, night club, pantai pijat dan Iain-lain) pariwisata tidak bisa berkembang. Sikap yang demikian adalah tidak beralasan. Bisa saja wisata tanpa menyajikan seks mendapat pesanan yang baik. Malah ada negara yang menyesali dirinya karena terlanjur mempromosikan seks sebagai andalan wisatanya, lebih-lebih dengan berkembangnya AIDS akhir-akhir ini. Sikap industri pariwisata seperti ini perlu dirobah dan diarahkan agar mereka yakin bahwa perusahaan dibidang pariwisata tanpa unsur seks juga bisa mendatangkan uang, Contoh di Mekah, dan Madinah.

Pembangunan sektor agama di Kabupaten Aceh Singkil merupakan bagian dari pembangunan daerah secara menyeluruh sekaligus sebagai mata rantai yang tidak terputus, berkelanjutan dan berkesinambungan dalam menciptakan landasan menuju cita-cita pembangunan dalam masyarakat yang selaras dan seimbang antara duniawi dan ukhrawi guna mencapai masyarakat adil dan makmur.

\section{KESIMPULAN}

1. Walaupun di Aceh Singkil penduduknya dominasi beragama Islam, namun tingkat toleransi terhadap agama lain terjalin baik, ini ditandai dengan banyaknya kunjungan wisatawan mancanegara (yang bukan beragama Islam) ke daerah ini, masyarakat tetap memperlakukannya dengan baik. Kemudian banyak terdapat Gereja hingga sekarang aman dari gangguan penduduk setempat.

2. Motivasi kunjungan berkaitan dengan kegiatan religius, disamping obyek kunjungan rekreasional sebagai obyek peninggalan sejarah oleh wisatawan umum. Dalam hal kunjungan wisatawan yang berkaitan dengan kegiatan keagamaan telah berkembang di Aceh Singkil, seperti halnya kunjungankunjungan yang dilakukan di makam ulama Syekh Abdul Rauf Al-Singkili dan Syekh Hamzah Fansury. 


\section{DAFTAR PUSTAKA}

\section{Al-Quran}

BPS. 2018. Aceh Singkil dalam angka 2018. Badan Pusat Statistik

Marpaung, Happy (2000), Pengetahuan Kepariwisataan (edisi revisi) Bandung, Alfabeta

Moleong, Lexy (2000), Metode Penelitian Kualitatif, Bandung, Remaja Rosda

Qanun Propinsi Nanggroe Aceh Darussalam No. 20 Tahun 2001

Rusidi (1992), Dasar-Dasar Penelitian dalam Rangka Pengembangan Ilmu Program Pascasarjana, Bandung. Unpad

Sukarsa, I Made (1999), Pengantar Pariwisata, Jakarta: Departemen P dan K Direktorat Jenderal Pendidikan Tinggi.

Tan, Nelly G (1997), Masalah Perencanaan dalam Motode Penelitian Masyarakat, Jakarta. Gramedia

Yoeti (1997), Pengembangan Pariwisata di Bali. Jakarta 